\title{
3. The exploration and exploitation of hydrocarbon resources in areas of overlapping claims
}

\section{Tara Davenport}

\section{INTRODUCTION}

The belief that there are untapped hydrocarbons in the seabed of the South China Sea has been one of the main reasons that the claimants to the Spratly Islands (Brunei, China, Malaysia, the Philippines, Viet Nam, and Taiwan) have vigorously defended their sovereignty claims over the features in the Spratly Islands. ${ }^{1}$ However, exploration and exploitation of such resources has been hindered by the various competing claims to sovereignty and sovereign rights in waters surrounding the Spratly Islands. The purpose of this chapter is to demonstrate that international law imposes certain rights and duties in relation to hydrocarbon resources in overlapping claim areas which constrain the conduct of the claimants in their exploration and exploitation of such resources. It argues that under both the 1982 United Nations Convention on the Law of the Sea (UNCLOS), ${ }^{2}$ and general international law, States are obliged to co-operate with each other in the management of resources in overlapping claim areas, although the exact nature and extent of such duties of co-operation will depend on the type of overlapping claim. The chapter concludes with an examination of the implications of such duties of co-operation for the South China Sea disputes.

\footnotetext{
1 It should be noted there is great disparity in the estimates of hydrocarbon resource potential: Clive Schofield, 'Dangerous Ground - A Geopolitical Overview of the South China Sea' in S Bateman and R Emmers (eds), The South China Sea: Towards a Cooperative Management Regime (Routledge: London, 2009), at 17.

2 United Nations Convention on the Law of the Sea, Adopted in Montego Bay, Jamaica, on 10 December 1982, UNTS 1833 at 397 (entered into force 16 November 1994). As of 29 November 2012, 163 States and the European Union were parties to UNCLOS, online: United Nations http://www.un.org/Depts/los/ convention_agreements/convention_overview_convention.htm.
} 
Part I will first discuss the regime for the exploration and exploitation of hydrocarbon resources under UNCLOS. Part II will examine how UNCLOS deals with the exploration and exploitation of resources in areas of overlapping claims. Part III explores other sources of international law which govern the use of hydrocarbon resources in overlapping claim areas and Part IV discusses joint development as a specific tool of resource management in overlapping claim areas. Finally, Part V examines the implications for the South China Sea disputes.

\section{THE EXPLORATION AND EXPLOITATION OF HYDROCARBON RESOURCES UNDER UNCLOS}

UNCLOS, which is generally considered to have established a 'constitution' $^{3}$ for the oceans, demarcates zones of juridical competence where different rights and obligations are extended to coastal States and other users of the sea. Undoubtedly, one of the major objectives of UNCLOS was to grant to the coastal State the right to explore and exploit its seabed resources. For present purposes, the most important zones in terms of hydrocarbon resources are the territorial sea, exclusive economic zone (EEZ) and the continental shelf.

\section{A. Territorial Sea}

Under UNCLOS, a coastal State's sovereignty extends beyond its land territory and internal waters to the territorial sea including its seabed and subsoil. ${ }^{4}$ A coastal State can establish a territorial sea up to 12 nautical miles (nm). ${ }^{5}$ Its sovereignty is subject to certain exceptions, ${ }^{6}$ but it is clear that a coastal State has exclusive property rights to hydrocarbon resources underneath its territorial sea.

3 Tommy TB Koh, 'A Constitution for the Oceans' (Statement by President Koh at the final session of the Conference at Montego Bay, 6 and 11 December 1982), reprinted in United Nations, The Law of the Sea: United Nations Convention on the Law of the Sea (1983) E.83.V.5.

4 UNCLOS, supra note 2, Art 2.

5 UNCLOS, supra note 2, Art 3.

6 These exceptions include the obligation to afforded to foreign vessels the right of innocent passage in the territorial sea (see UNCLOS, supra note 2, Part II, Section 3). 


\section{B. The Continental Shelf}

The continental shelf refers to the relatively shallow area of the seafloor adjacent to the coast where the continental margin slopes gradually from the landmass into the sea until it drops sharply towards the seafloor. ${ }^{7}$ The continental shelf contains a significant amount of oil and gas reserves and indeed, oil and gas reserves represent approximately 90 per cent of the total value of minerals taken from the seabed. ${ }^{8}$ The desire of coastal States to exploit these resources was the major motivating factor in the spate of unilateral claims to the continental shelf after the Second World War. ${ }^{9}$ This need to establish a legal regime to govern such claims to vast areas of ocean space led to the ultimate adoption of UNCLOS in 1982.

Under UNCLOS, the coastal State is entitled to a continental shelf up to $200 \mathrm{~nm},{ }^{10}$ or if certain criteria are met, it is entitled to an extended continental shelf. ${ }^{11}$ It 'exercises over the continental shelf sovereign rights for the purpose of exploring it and exploiting its natural resources' ${ }^{12}$ There was significant debate during the sessions of the International Law Commission (ILC) in the drafting of articles on the law of the sea with regard to the terminology that should be used to describe the nature of the coastal State's rights over the continental shelf. The crux of the debate was whether the term 'sovereignty' should be used or whether the terms 'jurisdiction and control' should be used instead. ${ }^{13}$ The term 'sovereign rights' was adopted as a compromise to break this stalemate. The ILC deliberately adopted the formula of 'sovereign rights':

... to avoid language lending itself to interpretations alien to an object which the Commission considers to be of decisive importance, namely the safeguarding of the principle of the full freedom of the superjacent sea and the airspace above it. Hence, it was unwilling to accept the sovereignty of the coastal State

7 D Rothwell and T Stephens, The International Law of the Sea (Oxford: Hart Publishing, 2010), at 98.

8 RR Churchill and AV Lowe, The Law of the Sea, 3rd edn (Manchester: Manchester University Press, 1999), at 141.

9 This began with the 1945 Truman Declaration by President Truman of the United States that the 'natural resources of the subsoil and seabed of the continental shelf beneath the high seas ... as appertaining to the United States', which was followed by similar claims by other States: See Churchill and Lowe, supra note 8, at $143-4$.

10 UNCLOS, supra note 2, Art 76(1).

11 UNCLOS, supra note 2, Arts 76(1) and (4).

12 UNCLOS, supra note 2, Art 77(1) (emphasis added).

13 Richard Barnes, Property Rights and Natural Resources (Oxford: Hart Publishing, 2009) at 273. 
over the seabed and subsoil of the continental shelf. On the other hand, the text now adopted leaves no doubt that the rights conferred upon the coastal State cover all rights necessary for and connected with the exploration and exploitation of the natural resources of the continental shelf. Such rights include jurisdiction in connection with the prevention and punishment of violations of the law. ${ }^{14}$

It is clear from the above that the reason UNCLOS uses 'sovereign rights' instead of 'sovereignty' is to remove any possibility of coastal States claiming sovereignty over the waters above the continental shelf. ${ }^{15}$ However, there is no doubt that the drafters of UNCLOS intended to confer exclusive rights over the resources of the seabed arguably akin to 'sovereignty'. This is also supported by the recognition in UNCLOS that such rights are 'exclusive in the sense that if the coastal State does not explore the continental shelf or exploit its natural resources, no one may undertake these activities without the express consent of the coastal State'16 and that these rights exist $a b$ initio and do not depend on occupation or express proclamation. ${ }^{17}$

Pursuant to their sovereign rights over the resources in the seabed, coastal States have the exclusive right to construct and to authorize and regulate the construction, operation and use of (1) artificial islands; (2) installations and structures for the exploration and exploitation of natural resources and other economic purposes; and (3) installations and structures which may interfere with the exercise of the rights of the coastal State in the continental shelf. ${ }^{18}$ Accordingly the coastal State has exclusive jurisdiction over the infrastructure used to explore and exploit oil and gas reserves within its continental shelf.

\section{The Exclusive Economic Zone}

The concept of the exclusive economic zone was initially motivated by the increasing assertion of States to exclusive fishing zones (EFZs) from

14 See 1956 ILC Draft Articles concerning the Law of the Sea with Commentaries, Yearbook of the International Law Commission, Volume II, UN Doc. A/3159 (1956), at 297.

15 This was not an unfounded fear, given the practice of States prior to the adoption of UNCLOS, to adopt $200 \mathrm{~nm}$ 'patrimonial seas' equivalent to territorial waters. See Churchill and Lowe, supra note 8, at 160.

16 UNCLOS, supra note 2, Art 77(2).

17 UNCLOS, supra note 2, Art 77(3).

18 UNCLOS, supra note 2, Art 80. 
their coasts. ${ }^{19}$ The EFZ developed in tandem with the sea-bed claims of States and it was inevitable that there was an attempt to merge claims to the water column and claims to seabed resources into 'one resource zone concept, combining the essential elements of both'. ${ }^{20}$ In 1971, during the negotiations of UNCLOS, Kenya proposed the concept of the EEZ to be a zone relating to all of the natural resources of adjacent seas, including the sea-bed and water column. ${ }^{21}$

UNCLOS allows coastal States to claim up to a $200 \mathrm{~nm}$ EEZ.22 The EEZ regime uses the same nomenclature of 'sovereign rights' adopted in the continental shelf regime. The coastal State has 'sovereign rights for the purpose of exploring and exploiting, conserving and managing the natural resources, whether living or non-living, of the waters superjacent to the seabed and of the seabed and its subsoil'. ${ }^{23}$

It should be borne in mind that the EEZ and the continental shelf now provide two distinct bases for coastal State rights over the seabed. However, the EEZ regime and continental shelf regime will usually apply concurrently to the same geographical area. ${ }^{24}$ In recognition of this, Article 56(3) of UNCLOS provides that the rights set out in the EEZ with respect to the seabed and subsoil shall be exercised in accordance with Part VI on the continental shelf.

Coastal States also have jurisdiction as provided for in UNCLOS with regard to the establishment and use of artificial islands, installations and structures. ${ }^{25}$ Article 60 of UNCLOS recognizes the exclusive right of the coastal State to construct and to authorize and regulate the construction, operation and use of (1) artificial islands; (2) installations and structures for the exploration and exploitation of natural resources and other economic purposes; and (3) installations and structures which

19 Rothwell and Stephens, supra note 7, at 83.

20 See Malcolm Evans, Relevant Circumstances and Maritime Delimitation (Oxford: Clarendon Press, 1989), at 34.

21 Rothwell and Stephens, supra note 7, at 83.

22 UNCLOS, supra note 2, Art 57.

23 UNCLOS, supra note 2, Art 56(1)(a).

24 The EEZ has a breadth of $200 \mathrm{~nm}$ (Article 57, UNCLOS) and the minimum breadth of the continental shelf is $200 \mathrm{~nm}$. It is said, ' $[\mathrm{h}] \mathrm{ad}$ it not been for a strong desire on the part of many coastal States, now reflected in the provisions of [UNCLOS], to include within the legal continental shelf those parts of the continental margin extending beyond 200 miles, the legal regime of the continental shelf could have been subsumed within the EEZ (emphasis added)'. See Churchill and Lowe, supra note 8, at 166.

25 UNCLOS, supra note 2, Art 56(1)(b). 
may interfere with the exercise of the rights of the coastal State in the zone. ${ }^{26}$

It is interesting to note that while the EEZ regime gives coastal States the general right to 'conserve and manage' hydrocarbon resources, UNCLOS contains no substantive provisions on the conservation and management of such resources. ${ }^{27}$ This is in contrast to living resources, where the EEZ regime imposes express obligations on the coastal State to conserve and utilize living resources in the EEZ in a sustainable manner. ${ }^{28}$

\section{Other UNCLOS Provisions Relevant to the Exploration and Exploitation of Hydrocarbon Resources}

As can be seen from above, UNCLOS places sole control over the exploration and exploitation of hydrocarbon resources with the coastal State. The establishment of the EEZ and continental shelf has reportedly placed 87 per cent of the world's known offshore hydrocarbon fields under coastal State jurisdiction. ${ }^{29}$ However, it should be remembered that the rights of the coastal State in relation to hydrocarbon resources do not exist in a vacuum and that UNCLOS was a 'package deal' that also placed obligations on coastal States in the exploration and exploitation of their hydrocarbon resources. While space constraints prohibit a detailed examination of such obligations, it is worth highlighting two of them. First, within the EEZ, coastal States must have due regard to the rights and duties of other States recognized under UNCLOS when exploring or exploiting their resources, ${ }^{30}$ such as the freedom of navigation and overflight and of the laying of submarine cables and pipelines. ${ }^{31}$ Second, UNCLOS has also established a sophisticated system for the protection of the marine environment in Part XII. Under this Part, it is explicitly recognized that States have a general obligation to protect and preserve the marine environment ${ }^{32}$ and their sovereign right to exploit their natural resources must be exercised in accordance with their duty to protect and preserve

\footnotetext{
26 UNCLOS, supra note 2, Art 60.

27 See generally David Ong, 'Towards an International Law for the Conservation of Offshore Hydrocarbon Resources within the Continental Shelf' in David Freestone, Richard Barnes and David M Ong, The Law of the Sea: Progress and Prospects (New York: Oxford University Press, 2006), at 93-120.

28 UNCLOS, supra note 2, Arts 61 and 62.

29 Churchill and Lowe, supra note 8, at 162.

30 UNCLOS, supra note 2, Article 56(2).

31 UNCLOS, supra note 2, Art 58(1).

32 UNCLOS, supra note 2, Art 192.
} 
this environment. ${ }^{33}$ In particular, Article 208 obliges States to adopt laws and regulations to prevent, reduce and control pollution of the marine environment arising from seabed activities subject to their jurisdiction and from artificial islands, installations and structures under their jurisdiction. While it is beyond the scope of this chapter to examine the international conventions and regulations applicable to the protection of the marine environment from seabed activities, it suffices to say that there are limits on a coastal State's right to explore and exploit its resources.

\section{EXPLORATION AND EXPLOITATION OF RESOURCES IN OVERLAPPING CLAIM AREAS UNDER UNCLOS}

In view of these numerous benefits to coastal States, particularly in terms of control over hydrocarbon resources, it is unsurprising that coastal States frequently make maritime claims to ocean space that maximize their maritime entitlements. This can result in a multitude of overlapping claims in which two or more States are asserting sovereignty or sovereign rights. Given the wide range of geographical configurations, there are various formulations of overlapping claims including (1) overlapping claims to territorial sea; (2) overlapping claims to EEZs; (3) overlapping claims to continental shelves; (4) overlapping claims between different maritime zones (for example, an overlapping claim between a territorial sea and an EEZ or an overlapping claim between a continental shelf and an EEZ); and (5) overlapping claims to a single maritime zone from disputed territory. While UNCLOS does have provisions on delimitation for the territorial sea, ${ }^{34} \mathrm{EEZ}^{35}$ and continental shelf, ${ }^{36}$ there is much room 'for radically differing interpretations as to which factors and methods of delimitation are appropriate to a particular case, and therefore potential for dispute and deadlock in delimitation negotiations'. ${ }^{37}$

The question is what are the rights and obligations of States in these areas of overlapping claims pending agreement on maritime delimitation? Prima facie, it would seem that the rights and jurisdictional competencies of the coastal State are in legal limbo, particularly with regard to their

\footnotetext{
33 UNCLOS, supra note 2, Art 194.

34 UNCLOS, supra note 2, Art 15.

35 UNCLOS, supra note 2, Art 74(1).

36 UNCLOS, supra note 2, Art 83.

37 V Prescott and C Schofield, The Maritime Political Boundaries of the World, 2nd edn (The Netherlands: Martinus Nijhoff Publishers, 2005), at 246.
} 
resource exploration and exploitation rights. This is especially so given the fact that any extraction has the potential to change the condition of the oil and gas reserve. ${ }^{38}$ Equally as important is the fact that any unilateral activity within an overlapping claim area is likely to exacerbate tensions between the States concerned. At the same time, the complete suspension of economic activity in areas of overlapping claims is also not a desirable situation.

UNCLOS does not contain a detailed or comprehensive regime for the exploitation or exploration of resources in overlapping claim areas. It does not contain any express provisions with regard to overlapping claims to a territorial sea or overlapping claims between different maritime zones or overlapping claims to a single maritime zone from disputed territory. Indeed, as will be discussed below, it only has one express provision relating to the rights and obligations of States in overlapping EEZ and continental shelf claims which arguably also does not address all the issues arising from overlapping claim areas. This will be discussed further below.

\section{A. Provisional Arrangements of a Practical Nature in Overlapping EEZ/ Continental Shelf Claims}

As mentioned above, during the negotiations for UNCLOS, it was recognized that delimitation negotiations could be a time-consuming process. Consequently, there were attempts to formulate some form of interim solution pending the delimitation of final boundaries. These interim solutions included a provisional interim median line boundary, ${ }^{39}$ as well as a moratorium on resource exploitation pending final delimitation and an obligation that States concerned make "provisional arrangements' 40 in the interim. The text ultimately adopted in paragraph 3 of Articles 74 and 83 stated:

[T]he States concerned, in a spirit of understanding and cooperation, shall make every effort to enter into provisional arrangements of a practical nature and during the transitional period, not to jeopardize or hamper the reaching of final agreement. Such arrangements shall be without prejudice to the final delimitation.

38 Ranier Lagoni, 'Oil and Gas Deposits Across National Frontiers' (1979) 73 AJIL 215, at 217.

39 For a description of the negotiating history of UNCLOS, see generally, Sun Pyo Kim, Maritime Delimitation and Interim Arrangements in North East Asia (The Netherlands: Martinus Nijhoff Publishers, 2004), at 32-7.

40 Ibid, at 34 . 
It is clear that there are two aspects to the obligation in Articles 74(3) and 83(3). First, States concerned shall make every effort to enter into provisional arrangements of a practical nature. Second, States, in good faith, shall make every effort not to jeopardize or hamper the reaching of the final delimitation agreement. Each aspect will be dealt with below. The two obligations 'simultaneously attempt to promote and limit activities in a disputed maritime area' ${ }^{41}$

\title{
1. Duty to make every effort to enter into provisional arrangements
}

The obligation of States to make every effort to enter into provisional arrangements of a practical nature has been succinctly summarized by scholars, based on judicial precedents such as the North Sea Continental Shelf Cases: ${ }^{42}$

\begin{abstract}
The states concerned are obliged 'to enter into negotiations with a view to arriving at an agreement' to establish provisional arrangements of a practical nature and ... 'not merely to go through a formal process of negotiation.' The negotiations are to be 'meaningful, which will not be the case when either [state] insists upon its own position without contemplating any modification of it.' However, the obligation to negotiate does not imply an obligation to reach agreement ...
\end{abstract}

This view was endorsed in a recent arbitration between Guyana and Suriname by an Arbitral Tribunal constituted under Annex VII of UNCLOS. In this maritime delimitation case, Guyana and Suriname both argued that the other had breached their obligations under Articles 74(3) and 83(3) stemming from Guyana's issuance of an oil exploration concession to CGX Resources, a Canadian oil company in 1998, in an area subject to overlapping continental shelf and EEZ claims. Suriname had demanded that Guyana and CGX cease all oil exploration activities in the overlapping claim area; however, in 2000, two Suriname naval vessels approached an oil and drill rig engaged by CGX and ordered it to leave Suriname waters within 12 hours. The crew subsequently withdrew from the overlapping claim area.

The Tribunal found that the while the language 'every effort' leaves 'some room for interpretation by the States concerned, or by any dispute settlement body', it imposes on the parties 'a duty to negotiate in good

41 Guyana v Suriname (2007) Arbitral Tribunal Constituted Pursuant To Article 287, And In Accordance With Annex VII of the United Nations Convention on The Law of the Sea, at para 459, online: PCA-CPA http://www.pca-cpa.org/showpage.asp?pag_id=1147.

42 Ranier Lagoni, 'Interim Measures Pending Maritime Delimitation Agreements' (1984) 78 AJIL 345, at 356. 
faith'. This requires the parties to take 'a conciliatory approach to negotiations, pursuant to which they would be prepared to make concessions in the pursuit of a provisional arrangement' ${ }^{43}$ Further, the obligation to negotiate in good faith 'is not merely a nonbinding recommendation or encouragement, but a mandatory rule whose breach would represent a violation of international law'. ${ }^{4}$

According to the Tribunal, both Suriname and Guyana had breached their obligation to negotiate provisional arrangements in good faith. When Suriname became aware of Guyana's exploratory efforts in disputed waters, instead of attempting to engage it in a dialogue which may have lead to a satisfactory solution for both Parties, it resorted to self-help in threatening the oil rig and drill ship in violation of UNCLOS. ${ }^{45}$ It also failed to engage in a last-minute dialogue proposed by Guyana prior to the CGX incident. ${ }^{46}$

Similarly, Guyana had also violated its obligation under Article 83(3) because it had failed to directly inform Suriname of its plans for exploratory drilling despite preparing for such drilling for some time, (CGX's public announcements were not sufficient notice), and it should have sought to engage Suriname in discussions concerning the drilling at a much earlier stage. ${ }^{47}$ The Tribunal then proceeded to give examples of actions that would be consistent with the obligation to 'make every effort' to enter into provisional arrangements including (1) giving Suriname official and detailed notice of the planned activities; (2) seeking the cooperation of Suriname in undertaking the activities; (3) offering to share the results of the exploration and giving Suriname an opportunity to observe the activities; and (4) offering to share all the financial benefits received from the exploratory activities. ${ }^{48}$

\section{Obligation of mutual restraint}

The second part of the obligation provides that during this transitional period, States are obliged not to jeopardize or hamper the reaching of a final agreement on delimitation. It is said that a court or tribunal's interpretation of this obligation must reflect the delicate balance between preventing unilateral activities that affect the other party's rights in a permanent manner but, at the same time, not stifling the parties' ability to

\footnotetext{
43 Guyana v Suriname, supra note 41, at para 461.

44 Lagoni, supra note 42, at 354.

45 Guyana v Suriname, supra note 41, at para 476.

46 Ibid.

47 Ibid, at para 477.

48 Ibid.
} 
pursue economic development in a disputed area during a time-consuming boundary dispute. ${ }^{49}$

International courts and tribunals have found that this obligation does not preclude all activities in a disputed area and only 'any activity which represents an irreparable prejudice to the final delimitation agreement' ${ }^{50}$ In this regard, a distinction is to be made between activities of the kind that lead to a permanent physical change, and those that do not. ${ }^{51}$ The former is prohibited whereas the latter is allowed. This distinction is based in part on the Aegean Sea Continental Shelf Case, ${ }^{52}$ which although it pre-dates UNCLOS and involves the application of provisional measures of protection, found that exploration activities that did not involve the establishment of installations or amount to an actual appropriation or other use of the natural resources in question did not justify the grant of an interim award of protection. Similarly, the Guyana v Suriname Arbitration found that allowing exploratory drilling in disputed waters was a breach of the obligation to make every effort not to hamper or jeopardize the reaching of a final agreement as this could result in a physical change to the marine environment and engender a 'perceived change to the status quo'. ${ }^{53}$ This was in contrast to seismic testing, which did not cause a physical change to the marine environment.

Interestingly, the Tribunal in Guyana $v$ Suriname also found that Suriname's actions in using the threat of force in getting the Guyanalicensed vessel to leave was also a breach of its obligation not to jeopardize the final agreement. ${ }^{54}$ Suriname 'had a number of peaceful options to address Guyana's authorization of exploratory drilling' such as the entry into discussions with Guyana concerning provisional arrangements and recourse to the compulsory dispute settlement procedures in Part XV of UNCLOS. 55

\section{B. A Critique of Provisional Arrangements as a Tool for the Management of Resources in Overlapping Claim Areas}

The decision in Guyana $v$ Suriname undeniably gives some teeth to the obligation to negotiate provisional arrangements in Articles 74(3) and

\footnotetext{
49 Ibid, at para 470.

50 Lagoni, supra note 42 , at 366.

51 Guyana $v$ Suriname, supra note 41, at para 467.

52 Aegean Sea Continental Shelf (Greece v Turkey) Interim Protection, 1976

ICJ Rep. 3 (Order of 11 September).

53 Guyana v Suriname, supra note 41, at para 480.

54 Ibid, at para 445.

55 Ibid, at paras 483 and 484.
} 
83(3) and is a welcome clarification of a provision which had not been subject to judicial interpretation before. It places positive obligations on State Parties to a dispute to co-operate in overlapping claim areas and encourages them to come to an agreement on the management of resources in such areas. The obligations placed on parties to co-operate and consult with each other and to refrain from activities which could have an irreparable effect has undoubted value in framing the conduct of States in areas of overlapping claim, not least of which is to reduce tension and conflict.

However, there are still issues remaining. First, there is still a considerable degree of uncertainty on the substantive content of this obligation. There is significant room for debate on what is meant by 'make every effort' and its interpretation as a duty to negotiate in good faith. While the Tribunal gave specific examples of what would evidence good faith negotiations (notice, consultation etc), there is a wide range of actions by States which would also support an argument that they have not fulfilled their duty to negotiate in good faith. Further, good faith negotiations on provisional arrangements (like negotiations on delimitation) could also continue for years without any resolution. It is clear that States are under no obligation to enter into any provisional arrangement but must only 'make every effort' to enter into such arrangements. While it has been suggested that a party may resort to the compulsory dispute settlement procedures under Section XV of UNCLOS if good faith negotiations are unsuccessful in producing a provisional arrangement within a reasonable period of time, ${ }^{56}$ what is meant by 'reasonable period of time' is again open to different interpretations.

Second, the fact that States have significant discretion on the type of provisional arrangements that should be adopted ${ }^{57}$ has its advantages and disadvantages. The primary advantage of such discretion is that it allows States the flexibility to adopt a wide range of provisional arrangements suitable to the particular circumstances of the case. Indeed, several authors have denounced the need for a legal obligation to adopt provisional arrangements (as opposed to the less onerous obligation to 'make every effort' to enter into provisional arrangements presently applicable). They argue that such an obligation is meaningless if there is no political

56 David Ong, 'Joint Development of Common Offshore Oil and Gas Deposits: 'Mere' State Practice or Customary International Law?' (1999) 93(4) AJIL 771, at 784.

57 Natalie Klein, 'Provisional Measures and Provisional Arrangements in Maritime Boundary Disputes' (2006) 21(4) Int'l J. Mar. \& Coast. L. 423, at 466. 
will to comply with such an obligation. ${ }^{58}$ There is certainly merit in this argument particularly if the States do not (or cannot) enforce compliance with this obligation through dispute settlement mechanisms. However, the wide discretion given to States may also undermine one of the objectives of UNCLOS and provisional arrangements to promote 'equitable and efficient utilization of the resources of the seas and oceans' ${ }^{59}$ As noted by one author: 60

... the provisions of international law concerning the assertion of these rights within [overlapping claim areas] are general in nature, emphasizing restraint, peaceful co-operation and commitment to negotiations. They do not establish a detailed or functionally comprehensive template for the provisional and cooperative implementation within an [overlapping claim area] of the functional components of coastal State jurisdiction. Rather, international law defers to claimant coastal States to reach agreement enabling them to manage activity within [overlapping claim areas] on a functionally comprehensive basis (thereby fully utilizing their coastal State rights under international law (emphasis added).

The deference to coastal States may lead to management regimes which are too focused on the exploration and exploitation of resources at the expense of other important public goods such as the marine environment.

Third, there is also some uncertainty as to where these provisional arrangements apply. Articles 74(3) and 83(4) do not specify the area to which the provisional arrangements apply, although some suggestions and proposals at the negotiations of UNCLOS contained references to specific geographical lines or areas. ${ }^{61}$ Ranier Lagoni opines that the obligation to negotiate provisional arrangements has a geographical connotation: ${ }^{62}$

In accordance with the above-mentioned object and purpose of paragraph 3 , the obligation applies only to those areas about which the governments hold opposing views. These views must be expressed formally, for example by

58 See for example, Ian Townsend-Gault and William Stormont, 'Offshore Petroleum Joint Development Arrangements: Functional Instrument? Compromise? Obligation?' in Gerald Blake, William Hildesley, Martin Pratt, Rebecca Ridley and Clive Schofield (eds), The Peaceful Management of Transboundary Resources (Great Britain: Graham \& Trotman Ltd and Kluwer Publishers Group, 1995), at 53.

59 UNCLOS, supra note 2, Preamble.

60 Ben Milligan, Legal and Policy Options for the Provisional Joint Management of Maritime Spaces Subject to Overlapping Jurisdictional Claims, PhD Thesis (personal copy with author), at 257.

61 Lagoni, supra note 42, at 356.

62 Ibid. 
declarations, or may be implied, for example through protests filed against the acts of other states or foreign nationals, by acts of the national legislator or by the granting of licenses and concessions.

However, this assumes that all unilateral claims are valid under international law. While it is true that international law requires States to make good faith claims ${ }^{63}$ which have a prima facie basis under international law, ${ }^{64}$ it is also true that many States do not comply with this obligation and tend to make claims which are to their greatest advantage. The fact that the obligation to negotiate provisional arrangements and exercise mutual restraint could extend to the whole of an overlapping claim area becomes particularly troubling when one considers the fact that States are constrained in the unilateral exploration and exploitation of resources in these areas. For example, if one State makes an extreme claim (that is, one which has little basis in international law), which overlaps with another State's claim, the former would be able to argue that the latter cannot exploit its resources in the area of overlapping claim. This would be particularly unfair and inequitable if the former's claim has no basis under international law.

A better view is that the area in which provisional arrangements apply is the area of overlapping entitlements (that is, claims which are validated under international law) rather than overlapping claims. The problem of course is how to determine whether a claim has a prima facie basis under international law, or rather, how does one party convince the other party that its claim has some basis in international law? Ultimately only a court can definitively decide what is valid under international law, and if States genuinely object to the invalidity of an entitlement (to be differentiated from disagreeing with delimitation principles), then they must be prepared to litigate the matter. Until then, parties to a dispute can only rely on the other party's 'own good faith interpretation of relevant legal principles and their application to the factual circumstances of a dispute ${ }^{95}$ and with all the disadvantages that entails.

63 When making claims to maritime space under UNCLOS, States are constrained by the obligation to make such claims in 'good faith' under both customary international law and UNCLOS: see Art 300 and Lagoni, supra note 42, at 356.

64 Xinjun Zhang, 'Why the 2008 Sino-Japanese Consensus on the East China Sea has Stalled: Good Faith and Reciprocity Considerations in Interim Measures Pending a Maritime Boundary Delimitation', (2011) 42 Ocean Devel \& Int'l L 53, at 59 .

65 Ibid. 


\section{OTHER SOURCES OF INTERNATIONAL LAW GOVERNING RESOURCES IN OVERLAPPING CLAIM AREAS}

Apart from Articles 74(3) and 83(3) discussed above, in recent years the question has arisen as to whether there is a rule of international law requiring co-operation in relation to common hydrocarbon resources found in overlapping claim areas. ${ }^{66}$ It is generally accepted under international law that States have an obligation to co-operate in relation to common or shared resources. While it is agreed that there is no specific international convention or well-established customary international law obligation to co-operate in relation to common or shared resources, other sources of international law, ${ }^{67}$ such as international conventions, international case law and General Assembly Resolutions, point to the existence of a general obligation to co-operate in relation to such resources. ${ }^{68}$

With regard to international conventions, the obligation to co-operate has been included in a variety of international treaties ${ }^{69}$ including a number of instances in UNCLOS. UNCLOS contains provisions relating to co-operation between States in the conservation and management of living resources, ${ }^{70}$ co-operation between States bordering an enclosed or semi-enclosed sea, ${ }^{71}$ co-operation in the protection of the marine environment $^{72}$ and co-operation in the development and transfer of technology. ${ }^{73}$

There are also certain UN General Assembly Resolutions which deal with rights over shared or common resources. ${ }^{74}$ For example,

\section{Ong, supra note 56, at 780.}

67 Under Article 38(1) of the Statute of the International Court of Justice, the traditional sources of international law are (1) international conventions, whether general or particular, establishing rules expressly recognized by the contesting States; (2) international custom as evidence of a general practice accepted as law, (3) general principles of law recognized by civilized nations, (4) subject to Article 59 of the ICJ Statute, judicial decisions and the teachings of the most highly qualified publicists of the various nations, as a subsidiary means for the determination of rules of law.

68 Ong, supra note 56, at 781.

69 Klein, supra note 57, at 466.

70 UNCLOS, supra note 2, Arts 61(2), 64, 65, 66, 117 and 118.

71 UNCLOS, supra note 2, Art 123.

72 UNCLOS, supra note 2, Section 2 of Part XII.

73 UNCLOS, supra note 2, Arts 144, 266-270.

74 Although it should be noted that UN General Assembly Resolutions are not considered binding rules of international law and are considered as related to 'customary international law' in that it can either serve as evidence of a convenient statement of custom already established by State practice or may also contribute to 
Article 3 of the 1974 Charter of Economic Rights and Duties of States provides: ${ }^{75}$

In the exploitation of natural resources shared by two or more countries, each State must co-operate on the basis of a system of information and prior consultations in order to achieve optimum use of such resources without causing damage to the legitimate interest of others.

There has also been recognition of the principle of co-operation in shared resources from the environmental perspective. The United Nations Environment Programme Guidelines, which have been endorsed by the UN General Assembly, call upon States 'to co-operate in the equitable utilization of shared natural resources and in the protection of the environment from the adverse effects of that utilization' and 'provide for exchange of information, notification of plans and consultations between interested states'. ${ }^{76}$

International case law, particularly decisions issued by ITLOS, has also emphasized a duty of co-operation. In the MOX Plant Case between Ireland and the UK, for example, while ITLOS refused to grant Ireland's requests for provisional measures relating to the commissioning of the MOX Plant and related maritime transport, it issued certain measures of co-operation, including requiring the parties to enter into consultations in relation to exchange of information, risk monitoring and devising 'as appropriate, measures to prevent pollution of the marine environment which might result from the operation of the MOX Plant'. ${ }^{77}$ Similarly, in the Land Reclamation Case between Singapore and Malaysia, ITLOS found that in view of the different positions of the parties on the possible repercussions of Singapore's land reclamation works and lack of co-operation between parties prior to the institution of proceedings, Singapore and Malaysia should co-operate and enter into consultations in respect of the prompt establishment of a group of experts, as well as the exchange of information on and assessment of risks or effects of Singapore's land rec-

the formation of custom as a kind of 'collective' state practice. See David Harris, Cases and Materials on International Law, 7th edn (United Kingdom: Thomson Reuters, 2010) at 54.

75 Charter of Economic Rights and Duties of States, GA Res 3281 (XXIX), UN GAOR, 29th Sess, Supp No 30, UN Doc. A/9030 (1974) at 50.

76 Ong, supra note 56, at 781.

77 The MOX Plant Case (Ireland v UK), Order of 3 December 2001, ITLOS Case No 10, (2002) 41 ILM 405, at para 89, online: ITLOS http://www.itlos.org/ fileadmin/itlos/documents/cases/case_no_10/Order.03.12.01.E.pdf. 
lamation works. ${ }^{78}$ ITLOS justified these measures of co-operation in both cases on the basis of a general obligation of co-operation imposed on States in relation to the protection and preservation of the marine environment in UNCLOS, rather than any specific duties of co-operation in UNCLOS. ${ }^{79}$

It is evident from the above that there is a general duty of co-operation under international law in relation to shared resources (including hydrocarbon resources in overlapping claim areas). While the existence of a general duty of co-operation under international law in relation to shared resources (including hydrocarbon resources in overlapping claim areas) is evident, the nature and extent of this duty is far from well-established. It would arguably entail consultation, notification, exchange of information and so on and an obligation to refrain from activities which would irreparably damage the shared resource to the detriment of the other party.

\section{THE INTERNATIONAL LEGAL FRAMEWORK GOVERNING JOINT DEVELOPMENT OF RESOURCES}

The concept of joint development of hydrocarbon resources appears to have emerged in the 1950s. ${ }^{80}$ However, despite considerable state practice since then, there is no common or uniform definition of joint development of hydrocarbon resources. ${ }^{81}$ It is usually used as a 'generic term' 82 and

78 Case Concerning Land Reclamation by Singapore in and around the Straits of Johor (Malaysia v. Singapore), Order of 8 October 2003), ITLOS Case No 12, at paras 93 - 106, online: ITLOS http://www.itlos.org/fileadmin/itlos/documents/ cases/case_no_12/Order.08.10.03.E.pdf.

79 See $M O X$ X Plant Case, supra note 77, at para 82; Land Reclamation Case, supra note 78 , at para 92.

80 Fox et al, Joint Development of Offshore Oil and Gas: A Model Agreement for States with Explanatory Commentary (Great Britain: British Institute of International and Comparative Law, 1989) at 54.

81 Thomas Mensah, 'Joint Development Zones as an Alternative Dispute Settlement Approach in Maritime Boundary Delimitation' in Ranier Lagoni and Daniel Vignes (eds), Maritime Delimitation (The Netherlands: Martinus Nijhoff Publishers, 2006) 143-53, at 146. For example, Mensah states that 'some scholars seek to distinguish between, on the one hand, 'unitization of shared resources' which they describe as an arrangement under which 'a single resource straddling an international boundary is developed subsequent to agreement without reference to such boundary' and on the other, joint development properly so called which they define as 'a regime under which the entire boundary dispute is set aside, thus creating an ambient development of political cooperation from the outset'.

82 Fox et al, supra note 80, at 43. 
extends from unitization of a single resource straddling an international boundary to joint development of a shared resource where boundary delimitation is shelved because it is not feasible or possible to reach an agreed boundary at the time.

There is no doubt that joint development arrangements are a type of 'provisional arrangement of a practical nature'. Their legal basis stems from Articles 74(3) and 83(3) of UNCLOS. Indeed, they appear to be the most commonly used arrangements for overlapping claim areas. International courts and tribunals have also endorsed joint development agreements as an alternative to maritime delimitation. ${ }^{83}$ For example, in the North Sea Continental Shelf Cases, the ICJ held that joint exploration agreements were "particularly appropriate when it is a question of preserving the unity of a deposit' in areas of overlapping claims. ${ }^{84}$ In his dissenting opinion in the 1982 continental shelf delimitation case between Tunisia and Libya, Judge ad hoc Evensen proposed a system of joint exploration of petroleum resources based on his view that joint development represented an alternative equitable solution to the maritime boundary dispute which was eventually adopted by the parties. ${ }^{85}$ In the Eritrea/Yemen Arbitration, the arbitral tribunal stated that the parties should give every consideration to the shared or joint or unitized exploitation of any such resources. ${ }^{86}$

There has been considerable doctrinal debate on whether there exists an obligation to enter into joint development arrangements. ${ }^{87}$ However, while joint development arrangements are a useful mechanism, it appears clear that States do not have a specific duty to enter into joint development arrangements in areas of overlapping claims. First, there is no international convention which specifies this obligation. Articles 74(3) and 83(3) leave it to the discretion of the States as to what type of provisional arrangement they may enter into and, again, it is merely an obligation to negotiate in good faith. Article 123 provides that States bordering an enclosed or semienclosed sea should co-operate with each other, but it imposes no 'specific

83 Guyana v Suriname, supra note 41, at para 463.

84 North Sea Continental Shelf Sea Cases (Federal Republic of Germany/ Denmark; Federal Republic of Germany/Netherlands) [1969] ICJ Rep 51, at para 99.

85 Ong, supra note 56, at 787.

86 The Government of the State of Eritrea $v$ The Government of the Republic of Yemen (1999), 119 ILR at 417, (1999), Award Of the Arbitral Tribunal In The Second Stage Of The Proceedings (Maritime Delimitation), online: PCA-CPA http://www.pca-cpa.org/showpage.asp?pag_id=1160.

87 For a summary of the two opposing schools of thought, see Chidinma Bernadine Okafor, 'Joint Development: An Alternative Legal Approach to Oil and Gas Exploitation in the Nigeria-Cameroon Maritime Boundary Dispute?' (2006) 21(4) Int'1 J. Mar. \& Coast. L. at 506-9. 
and legally enforceable' obligation on these States, as its language is more 'exhortatory than obligatory'. ${ }^{88}$ Also, the call for co-operation in the article is limited to conservation of marine living resources, protection of the marine environment and co-ordination of marine scientific research. It does not include the joint development of hydrocarbon resources. ${ }^{89}$

Second, there is also no customary international law obligation to enter into joint development agreements. Customary international law consists of State practice, which must be both constant and uniform and common to a significant number of States, particularly those States whose interests are specially affected, and there must be opinio juris in that States must recognize that this practice constitutes law binding on them. ${ }^{90}$ While there is arguably widespread State practice on joint development in many areas of the world, it does not appear to be constant or uniform. Nor does it appear to be a result of the fact that States believe they are under a legal obligation to enter into such agreements. ${ }^{91}$

\section{CONCLUSIONS: IMPLICATIONS FOR THE SOUTH CHINA SEA DISPUTES}

The above analysis suggests that the following rights and obligations exist in relation to hydrocarbon resources in overlapping claim areas.

First, in all overlapping claim areas (that is, overlapping claims to a territorial sea, overlapping claim to EEZs and continental shelves, overlapping claims to different maritime zones and overlapping claims to a single maritime zone from a disputed territory) there is a general obligation to co-operate in relation to resources. However, this is a general obligation and the nature and extent of this duty is far from well-established.

Second, in areas of overlapping EEZ and continental shelf claims, there are specific obligations stemming from Articles 74(3) and 83(3). These are, first, to enter into negotiations in good faith with a view toward arriving at a suitable co-operative arrangement. Second, States must exercise mutual

\footnotetext{
88 Ong, supra note 56, at 781.

89 Ong, supra note 56, at 782.

90 See Martin Dixon, Textbook on International Law, 6th edn (New York: Oxford University Press, 2007) at 30-7.

91 Ian Townsend-Gault and William Stormont, 'Offshore Petroleum Joint Development Arrangements: Functional Instrument? Compromise? Obligation?' in Gerald Blake, et al (eds), The Peaceful Management of Transboundary Resources (Great Britain: Graham \& Trotman Ltd and Kluwer Publishers Group, 1995), at 53.
} 
restraint and refrain from any behavior that could jeopardize the reaching of a final agreement. With regard to exploration and exploitation rights, it is clear from Guyana $v$ Suriname, that a State must inform, notify and consult the other State if it is carrying out unilateral exploration of hydrocarbon resources. Further, it cannot unilaterally exploit hydrocarbon resources without the consent of the other State.

What is the implication of this for the South China Sea? The first problem in determining the applicability of these obligations is the lack of clarity on the overlapping claim area. Although all the claimants have made claims to a territorial sea, EEZ and continental shelf from their mainland, ${ }^{92}$ the Southeast Asian Claimants (Malaysia, Brunei, Viet Nam and the Philippines) have not made claims from the Spratly Island features. China, on the other hand, has officially stated that the Spratly Islands are entitled to a territorial sea, EEZ and continental shelf $\mathrm{f}^{93}$ but has not defined baselines or maritime zones from such baselines. It is further complicated by the fact that it is not clear which of these features would be entitled to an EEZ and continental shelf under Article 121.

Undoubtedly, there is potentially an exceedingly complex layer of overlapping claims. First, there are potential overlapping claims between the EEZ and continental shelves claimed from the mainland of claimants and an EEZ and continental shelf from islands which are entitled to such zones under Article 121. Second, given that sovereignty over the Spratly features has not been decided, there are also potentially overlapping territorial sea claims between islands which are above water at high tide and entitled to a $12 \mathrm{~nm}$ territorial sea under UNCLOS. ${ }^{94}$ Third, there are potentially overlapping EEZ and continental shelf claims between islands which are capable of sustaining human habitation or an economic life of their own. Fourth, there are potentially overlapping claims from the EEZ/continental shelves from the mainland and the territorial sea of islands in the Spratlys. Fifth, there are also potentially overlapping claims from a single feature which is disputed between several claimants (for example, the territorial

\footnotetext{
92 See Chapter 2: 'International Law, UNCLOS and the South China Sea' by Robert Beckman, at 81-83.

93 See Note from the Permanent Mission of the People's Republic of China to the Secretary-General of the United Nations, CML/8/2011, 14 April 2011, online: United Nations http://www.un.org/Depts/los/clcs_new/submissions_files/ mysvnm33_09/chn_2011_re_phl_e.pdf.

94 Under Article 121, all islands (that is, features above water at high tide) are entitled to a $12 \mathrm{~nm}$ territorial sea. Overlapping territorial sea claims between the islands could theoretically occur if two islands close to each other are found to be under the sovereignty of different claimants.
} 
sea around Scarborough Shoal, claimed by both the Philippines and China, would also be claimed by both the Philippines and China).

The obligation under Articles 74(3) and 83(3) to negotiate provisional arrangements of a practical nature applies to overlapping EEZ and continental shelf claims. It is not clear whether they would apply to overlapping EEZ/continental shelf claims which have not crystallized as yet, although one noted author has argued that such obligations would apply even though negotiations on maritime delimitation have not begun and even though the overlapping claim area has not been defined due to the lack of clarity in both the sovereignty and maritime zone claims of the claimant States. ${ }^{95}$

The second issue in the application of the Articles 74(3) and 83(3) obligation is that it, in principle, only applies to overlapping EEZ/continental shelf claims and not to all the other various permutations of overlapping claims that could occur in the South China Sea. Of course, one could argue that the general duty of co-operation in relation to resources in overlapping claim areas would apply, and a court or tribunal deciding this issue could very well decide to impose the specific duties found in Articles 74(3) and 83(3).

The importance of determining (1) the geographical scope and nature of the overlapping claims as well as (2) the rights and obligations of the claimants in such overlapping claims should not be underestimated. The unilateral exploration activities of some of the claimants in areas of the South China Sea have been a consistent source of tension in the region and some of them have also indicated that they would be carrying out exploratory drilling in the near future in areas that have been claimed by other claimants.

If agreement could be reached on the status of all of the features and the maritime zones to which they are entitled, the disputed areas, or overlapping claims areas, would then be clearer. It would then be possible to at the very least begin discussions on provisional arrangements of a practical nature in these disputed areas.

95 As mentioned above, Ranier Lagoni has observed that the obligations in Articles 74(3) and 83(3) may arise in 'exceptional situations even if no definite claim can be asserted because the principles of delimitation are at issue, or because the delimitation is contingent on the resolution of a dispute over sovereignty of an island': see Lagoni, supra note 42, at 357. 